\title{
The Use of EU Structural Funds for Sustainable Development in Lithuania
}

\author{
Rimantas Dapkus and Dalia Streimikiene
}

\begin{abstract}
The aim of the paper is to review the use of EU structural funds for first and second programming period and to identify the main achievements and challenges in ensuring sustainable economy growth and cohesion in Lithuania The main tasks to achieve this aim are: to analyse aims and financing priorities from EU structural funds in the first financing period in Lithuania; to analyse use of EU structural funds in second financing period in Lithuania and to compare with results of use of EU Structural funds in other countries.
\end{abstract}

Index Terms-Cohesion, EU structural funds, regional development, sustainable economy growth.

\section{INTRODUCTION}

Structural Funds are the European Union's main instruments for supporting social and economic restructuring across the Union. They account for over a third of the European Union budget. There are four Structural Funds: ERDF, ESF, EAGGF and FIFG, which contribute to the economic development of disadvantaged regions. A region may have access to one or more of the four structural funds, depending whether it has Objective 1 or 2 status; all regions have Objective 3 status [1]. The aims of the funds, and in which priority 'Objective' area they can be spent, are set out below [2]:

The European Regional Development Fund (ERDF) aims to improve economic prosperity and social inclusion by investing in projects to promote development and encourage the diversification of industry into other sectors in areas lagging behind. This fund is available in Objective 1 and 2 areas.

The European Social Fund (ESF) funds training, human resources and equal opportunities schemes to promote employability of people in both Objective 1 and 3 areas. In Objective 2 areas ESF may be used to complement the ERDF activities.

The European Agricultural Guidance and Guarantee Fund (EAGGF) is available in rural Objective 1 areas to encourage the restructuring and diversification of rural areas, to promote economic prosperity and social inclusion, whilst protecting and maintaining the environment and our rural heritage.

Manuscript received June 10, 2013; revised September 5, 2013.

Rimantas Dapkus is with the Regional Development Department at Kaunas University of Technology, K.Donelaicio str. 20, Kaunas LT- 44239, Lithuania (e-mail: Rimantas.Dapkus@gmail.com).

Dalia Streimikiene is with the Vilnius University, Kaunas Faculty of Humanities, Muitines str. 8, Kaunas LT-44403, Lithuania (e-mail: dalia@mail.lei.lt).
The Financial Instrument for Fisheries Guidance (FIFG) funds projects to modernize the structure of the fisheries sector and related industries and to encourage diversification of the workforce and fisheries industry into other sectors. It also aims to ensure the future of the industry through achieving a balance between fisheries resources and their exploitation.

Most structural fund spending is targeted on specific regions, known as Objective 1, 2 and 3 regions. The national and regional bodies responsible have been preparing programmers for the 2000-2006 periods. The programmers must be approved by the Commission; set out below are the various stages in the approval process that programmers have reached [2].

Objective 1: Eligible areas are those that have less than $75 \%$ of EU average GDP. It is the highest level of regional funding available from the EU. It is aimed at promoting the development and structural adjustment of the EU regions most lagging behind in development.

Objective 2: Aims to support the economic and social conversion of areas facing structural difficulties. It is the second highest level of funding available from the EU. Areas qualify for Objective 2, under four strands - industrial, rural, urban and fisheries.

Objective 3: This Objective involves only the European Social Fund. It aims to develop labor markets and human resources and in addition, will help firms and workers adapt to new working conditions and so compete more effectively in global labor markets. It is directed at the long-term unemployed and those facing particular barriers to finding fulfilling employment because of their disability, racial origin, or sex.

In addition to the priority Objective areas around 5\% of the Structural Fund budget fund four Community Initiatives [2]:

- EQUAL - funds training and employability schemes to combat discrimination and inequalities in the labor market;

- LEADER + - funds rural development projects;

- INTERREG - provides funding to encourage cross border, trans-national and interregional co-operation; to encourage balanced and sustainable development across the European Community.

- URBAN - funds schemes in small and medium sized towns suffering from significant economic and social conversion difficulties.

EU structural funds are the main source of festering Lithuanian economic growth and investing. In 2005, the Lithuanian GDP per capita amounted to $47 \%$ of that of the EU-15 average. In Portugal this indicator was equal to $65.8 \%$, in Greece - 77\%, and in Spain - 90.7\%. 


\section{FIRST PRogramming PERIOD 2004-2006}

A National Plan was submitted by national governments to the European Commission in support of its request for aid from the Structural Funds in first programming period 2004-2006. For the purpose of consultation the countries are usually divided into sub-regions. The Plan generally proposes actions to improve the productive capacity of the economy; to encourage competitiveness and efficiency; to exploit the development potential of local initiatives, including area-based approaches targeted at disadvantaged areas; to develop skills and aptitudes of those seeking work; and to integrate those who are marginalized and disadvantaged into the workforce.

The official agreement between the Commission and the national governments on the amount and form of EU assistance for the National Development Plan takes the form of a Community Support Framework (CSF). The CSF contains a clause on environmental policy which states that all activities receiving EU funds must be in keeping with EU law and policies, including those on environmental protection. Member States are also obliged to supply the Commission with the appropriate information to enable them to evaluate the impact of operations or measures likely to have a significant impact on the environment.

The individual strategies outlined in the CSF, which in turn were based on the strategies outlined in the National Development Plan, are given practical expression by Operational Programmers which set out in more detail the particular measures which are assisted by the Structural Funds. The programmers are approved by the Commission and form the legal basis for the draw-down of assistance from the EU. Each programmer is drawn up by the relevant Government Department or official agency [2].

EU structural support funds represent significant assistance to the modernization and development of Lithuania's economy. Lithuanian GDP per capita is below $75 \%$ of the European Union's average and all territory of Lithuania is classified under Objective 1 and is able to draw on support from the EU Structural Funds. Lithuania is also able to draw funds from Objective 2 and Objective 3. The Lithuanian Single Programming Document and its supplement for 2004-2006 defines the main strategy for the use of SF in Lithuania and is the final result of internal negotiations within Lithuania between many different public and non-public authorities as well as other stakeholders, followed by an intensive period of negotiations with the European Commission. The rules of EU Structural Funds Projects Administration and Financing were approved by the Minister of Finance on 31st May 2004.

The Lithuanian Single Programming Document (SPD) is being implemented by specific strategies described in five Operational Programmers (OPs) [3]:

- Development of social and economic infrastructure,

- Development of human resources,

- Development of productive sector and services,

- Rural development and fisheries,

- Technical assistance.

The main target or priority of Lithuanian SPD is to strengthen the preconditions for growth in long-term national economic competitiveness and to facilitate the transition to and development of a knowledge-based economy characterized by increasing GDP levels and strong employment growth, leading to higher living standards and increasing well-being for all Lithuania's inhabitants.

There were five OP in Lithuania for the period 2004-2006 within the Community Support Framework. The total amount of SF support for 2004-2006 in Lithuania was 895.1 MEUR. The global objective of the OP Development of social and economic infrastructure is to develop new and improve existing physical infrastructure in order to promote economic growth and facilitate the free movement of goods, services and people and to ensure that development supported through the SPD is compatible with the principle of sustainable development. Its Community support reached 347 million EUR. The main objective of OP Development of Human Resources is to improve the skills base of the Lithuanian labor force and to ensure that the workforce is both flexible and adaptable. Another key objective is to upgrade skills and qualifications particularly amongst disadvantaged groups such as the unemployed and young people and to ensure that skills and competencies taught are relevant to labour market requirements. Its Community support reached 163.8 million EUR.

The main priorities of OP Development of Productive sector and Services are to strengthen economic competitiveness by creating the necessary framework conditions for growth, the promotion of a favorable business environment and investment climate conducive to the growth and development of both existing businesses and new business start-ups. The overall target of this OP is to strengthen the process of economic restructuring which is already underway in Lithuania. Its Community support should reach 222.4 million EUR.

The main priorities of OP Rural Development and Fisheries is to is to modernize agricultural holdings and stabilize the demographic situation in rural areas by creating suitable conditions to live and work in the countryside. Other important objectives are to ensure professional qualification of people engaged in agriculture and to establish general conditions for market organization, improvement of fishing conditions and mitigation of social impacts of fishing activities cessation in Lithuania. Its Community support reached 135 million EUR.

The Technical Assistance OP aims at ensuring the quality and effectiveness of all steps of preparation, evaluation, monitoring of the SF assistance at all levels of administration and public awareness about structural funds rising involving a wide range of partners in EU assistance planning and monitoring processes and also to ensure effective planning of future investment. Its Community support reached 26.8 million EUR.

\section{SECOND PROGRAMMING PERIOD 2007-2013}

Total allocation of EU structural assistance for Lithuania for the period 2007-2013, provided from the European Social Fund, European Regional Development Fund and Cohesion fund, amounts more than 23 billion Litas. This equals to an 
additional annual state budge [3].

EU structural assistance for Lithuania for the period 2007-2013 will be allocated in accordance with National general strategy: the Lithuanian Strategy for the use of European Union Structural Assistance for 2007-2013 (approved the European Commission on the 26th of April, 2007) and with operational programs for implementation of this strategy.

Primary purpose of employment of EU structural assistance, according to the strategy, is to rapidly improve conditions to invest, work and live in Lithuania, to support economy so its products would reach all citizens of Lithuania. Operational programmers will support implementation of goals and tasks set in the strategy [4].

Operational Programmer for the Development of Human Resources for 2007-2013 is dedicated to mobilization of all employable Lithuanian citizens, since investments to knowledge, competence, activity and enterprise of people of Lithuania ensures long term economical growth. $13.8 \%$ of EU structural funds are allocated to this program.

It is estimated that the largest part of funds $-45.72 \%$ - will be allocated to Operational programmer for the Economical Growth for 2007-2013. Extremely important is that $10 \%$ will be allocated to scientific researches and technological development of competitiveness and growth of economy.

Operational Programmer for Promotion of Cohesion for 2007-2013 should embody a vision of more harmonious society. For improvement of environment and quality of residency, by minimizing differences between separate regions, it is allocated $39.08 \%$ of total funds from EU structural assistance for the period 2007-2013.

Technical assistance Operational Programmer for 2007-2013 - is a special program for administration of thematic programs of actions. 1.4\% of EU structural funds were allocated for this programmer. An Operational programmer is the document submitted by a member state and approved by the European Commission with consistent priorities that can be implemented out of assistance funds. A specific action programmer can be financed only by the European Social Fund or the Cohesion Fund and/or the European Regional Development Fund. The Resolution of the Government of the Republic of Lithuania of 14 December 2005 No. 1351 has also obligated the Commission to develop the Strategy for the Use of EU Structural Funds in 2007-2013 period and to identify the Operational Programmers with responsibility of the drafting of Operational Programmers and the functions related to the formation of working groups. In the course of working out proposals for the Operational Programmers, a public discussion took place on 29 September 2005 to discuss a possible thematic grouping of the Strategy priority directions into Operational Programmers and the issues of organizing the development of such Operational Programmers. The proposals to the Operational Programmers, which have been prepared by the Commission and discussed with social, economic and regional partners, were submitted for consideration of the Government that has identified the following 3 Operational Programmers by its Resolution of 14 December 2005 No. 1351 "On setting Operational Programmers for implementing the Lithuanian Strategy for the use of EU Structural Funds for 2007-2013":
- Human Resources Development Operational Programmer;

- Economic Growth Operational Programmer;

- Cohesion Promotion Operational Programmer.

The Operational Programmers were developed by specific working groups consisting not only of the representatives from state authorities, but also from representative partners (as specified in Resolution of the Government of the Republic of Lithuania of 14 December 2005 No. 1351 that sets forth Operational Programmers).The working groups to develop Operational Programmers have been approved by the Order of the Minister of Finance of the Republic of Lithuania of 27 February 2006 No. 1K-070 "On the personal composition of the working groups to develop Operational Programmers".

Total EU funds allocated for Lithuania in 2007-2013 period makes more than 7.4 billion EUR. Contracts signed for 6.8 billion EUR and Funds paid out 4.4 billion EUR. The contracts signed refers to the funds of EU Funds and co-financing funds from the State budget of the Republic of Lithuania allocated for projects in project financing and administration contracts signed. The Funds paid out to the projects means the funds paid out to beneficiaries and contractors (service providers and suppliers of goods), including advance payments. Expenditure recognized as declarable to the EC - expenditure incurred by beneficiaries and verified by implementing bodies and recognized as eligible funds of the EU Funds and co-financing funds from the State budget of the Republic of Lithuania. Comparing with funding in 2004-2006 period which amounted to 895.1 million EUR sum allocated for the second period is significantly higher.

One can notice from Fig. 1 that the funds requested and funds paid were steadily growing during 2007-2008.

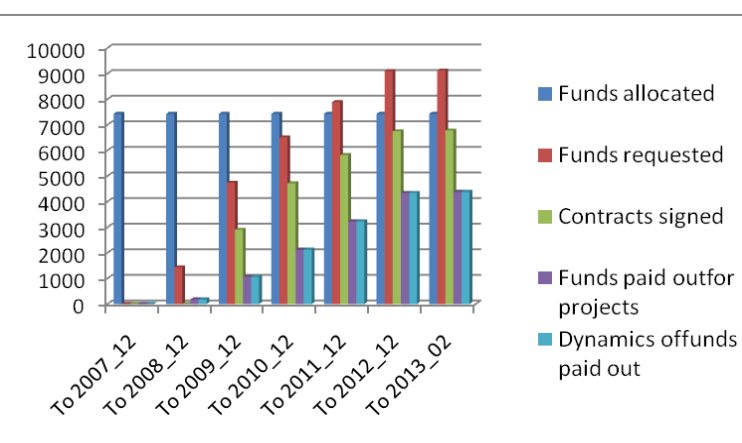

Fig. 1. The breakdown of EU structural funds allocated and paid during 2007-2013 is presented, billion EUR.

The European Commission has adopted a draft legislative package which will frame cohesion policy for 2014-2020 periods. The new proposals are designed to reinforce the strategic dimension of the policy and to ensure that EU investment is targeted on Europe's long-term goals for growth and jobs ("Europe 2020"). Through Partnership Contracts agreed with the Commission, Member States will commit to focusing on fewer investment priorities in line with these objectives. The package also harmonizes the rules related to different funds, including rural development and maritime and fisheries, to increase the coherence of EU action.

The discussions on the new policy priorities for next programming period 2014-2020 have not gained acceleration 
yet in Lithuania. Based on the results of previous evaluations, major challenges for the next programming period are related to the innovation demand-side policies, internationalization, entrepreneurship, innovation support services, and ensuring the sustainability of large scale R\&D infrastructure development projects launched during this period (e.g. the integrated science, business and studies 'valleys' projects.

\section{COMPARATIVE ASSESSMENT OF EU STRUCTURAL FUNDS SUPPORT IMPACT ON SUSTAINABLE DEVELOPMENT IN LITHUANIA AND OTHER NEW EU MEMBER STATES}

EU funded projects are expected to contribute to sustainable development. Realization of projects in bigger percentage is assigned to more developed countries with better project management knowledge [4]. However it is still not clear the efficiency of use of EU structural aid in implementing sustainable development [5].

The absorption of EU funds is a measurement of the EU funds usage, but also a measurement of fulfillment of the task to accelerate development of the states, and build a common European cohesion. Specific importance of the EU funds, which is often neglected, may be considered as a focus on development of certain sectors. By pushing the development of certain areas, EU funds can contribute to the long-term development and survival of European countries and its citizens. This aspect should be taken in consideration. It is necessary to discuss the use of EU funds from the view of forcing sustainable development of the EU countries and the whole EU. This is a new approach that considers EU funded project management as a specific process. The measure of its success can be analyzed in different ways [6].

The relationship between Happy Planet Index which reflects sustainable development of countries was applied as indicator to assess the effects of projects implemented through EU funded programs. It was expected that HPI should show if such financed projects satisfy target of the EU to protect the environment and ensure sustainable development of the country. Happy Planet Indexes are published by NEF every year for different countries. The HPI index does not necessary reveal the country with the highest level of happiness in the world. However, it indicates the relative efficiency of the nations, when they convert the planet's natural resources into long and happy lives for their citizens. It also shows that there are different ways to achieve comparable levels of well-being. The model followed by the West can provide widespread longevity and variable life satisfaction, but it does so only at a vast and ultimately counter-productive cost in terms of resource consumption.

The HPI explains the economy perspective right back to its basic simplicity: what we input (resources), and what are the output (human lives of different length and different levels of happiness). The HPI value of each country is calculated as a function of it's:

- Average subjective life satisfaction,

- Life expectancy at birth,

- Ecological footprint per capita.

In Table I HPI index and EU Structural Funds support per capita of a country are presented [7].
TABLE I: THE ARRANGEMENT OF CHANNELS

\begin{tabular}{|l|r|r|r|r|}
\hline & $\begin{array}{c}\text { Realized EU } \\
\text { structural } \\
\text { funds aid, \% } \\
\text { from total } \\
\mathbf{2 0 0 6}\end{array}$ & $\begin{array}{c}\text { HPI } \\
\mathbf{2 0 0 6} \\
\text { Country }\end{array}$ & $\begin{array}{c}\text { Realized EU } \\
\text { structural } \\
\text { funds aid, \% } \\
\text { from total } \\
\mathbf{2 0 0 9}\end{array}$ & $\begin{array}{c}\text { HPI } \\
\mathbf{2 0 0 9}(\mathbf{Y} \text { i) }\end{array}$ \\
\hline Romania & 97,41 & 37,7 & 27 & 43,9 \\
\hline Bulgaria & 182,59 & 31,6 & 198 & 42,8 \\
\hline Slovakia & 113,55 & 35,8 & 59 & 42 \\
\hline Estonia & 232,54 & 22,7 & 252 & 38,3 \\
\hline Poland & 93,23 & 42,8 & 131 & 43,5 \\
\hline Czech & 19,94 & 38,3 & 426 & 36,7 \\
\hline Latvia & 161,59 & 36,7 & 342 & 38,9 \\
\hline Lithuania & 215,62 & 40,9 & 470 & 40,9 \\
\hline Hungary & 133,07 & 38,9 & 443 & 26,4 \\
\hline Total & 1249,58 & & 2354 & \\
\hline
\end{tabular}

Source:

http://www.happyplanetindex.org/public-data/files/happy-planet-index-first -global.pdf

As one can see from the Table I though Lithuania has received comparable high aid from EU structural funds per capita in 2006 and 2009 according HPI Lithuania is ranked at lower rate than Poland which has received less EU structural fund support per capita in 2006. Estonia has received the highest support from EU structural funds in 2006 however has the lowest HPI. There was also investigated the impact of EU structural support per capita impact on GHG emissions and other indicators and didn't find positive correlation between EU structural support per capita and these indicators [8]. Of course such type of analysis has limitation and additional indicators need to be explored in more details.

\section{CONCLUSION}

1) EU Structural Funds is a good tool which can be used in new member states to attract investments for the financing of new technologies, including use of renewable energy sources and energy efficiency improvements (renewable energy projects) which are doubly underpowered by energy markets and needs state support.

2) Lithuanian benefited in the first programming period 2004-2006 by 895.1 million EUR from EU structural Funds and by 7.4 billion EUR in second programming period 2007-2013.

3) Operational Programmers (OPs) of the Structural Fund implementation in Lithuania during 2007-2013 have not sufficiently explored the chance to invest into innovation demand. The potential to link the demand for modernization to improve internal innovation capability is thus not fully realized.

4) The preparation for the current period (2007-2013) took longer than expected, consequently causing a significant delay in the implementation of most policy measures (some were delayed by 2-4 years).

5) The discussions on the new policy priorities for next programming period 2014-2020 have not gained 
acceleration yet in Lithuania. Based on the results of previous evaluations, major challenges for the next programming period are related to the innovation demand-side policies, internationalization, entrepreneurship, innovation support services, and ensuring the sustainability of large scale $R \& D$ infrastructure development projects launched during this period (e.g. the integrated science, business and studies 'valleys' projects).

6) Some empirical results showed that contribution of the EU funded projects is still not sufficient to make a significant influence on the sustainable development of the country.

7) Lithuania has received comparable high aid from EU structural funds per capita in 2006 and 2009 however according to HPI Lithuania is ranked at lower rate than Poland which has received significantly less EU structural fund support per capita in 2006 and 2009.

\section{REFERENCES}

[1] A. Horvat and G. Maier, Absorption Problems in the EU Structural Funds, Ljubljana, NARG, Strukturnifondovi, 2004, pp. 112-135.

[2] D. Štreimikienè, V. Klevas, and J. Bubelienè, "Use of EU Structural Funds for sustainable energy development in new EU member states," Renewable and Sustainable Energy Review, vol. 11, Issue 6, pp. 1167-1187 2007.

[3] V. Kvainauskaite and V. Kardokaitè, "Structural funds as instruments for regional economic development in Lithuania," Engineering Economics, vol. 2, no. 42, pp. 26-34, 2005.

[4] B. Melnikas, "The global transformations, sustainable development and the knowledge based society creation: The perspective theoretical approach," Business \& Economics, vol. 10, no. 2(23), pp. 151-168, 2011.

[5] V. Marinov, H. Bahloul, and B. Slay, "Structural funds and the new member states: lessons learned," London, Development \& Transition, issue 4, UNDP, London school of economics, pp. 97, 2006.

[6] EU funds in Central and Eastern Europe (CEE), Progress Report 2007-09, Budapest, KPMG, pp. 27, 2010.

[7] M. Kranjac, R. Maksimović, and U. Sikimić, "A model of using IPA funds for project realization in pre-accession countries: The case of Serbia," Economics, vol. 89, no. 2, pp. 115-123, 2010.

[8] M. Kranjac, Ch. Heny, and U. Sikimić, "European funds as fact of sustainable development in central eastern European countries, Facta Universitatis," Series: Economics and Organization, vol. 8, no. 3, pp. 301-312, 2011

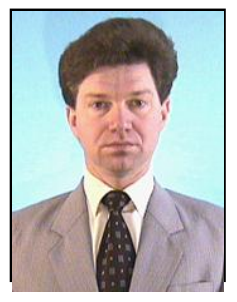

Rimantas Dapkus was born in Lithuania in 1959. In 1982 he has graduated Kaunas Polytechnic Institute (at present Kaunas University of Technology) and become diploma engineer in computing sciences. In 1995 he obtained a degree of doctor of the technical sciences and in 2009 become an assoc. professor of the social sciences at Kaunas University of Technology (Kaunas, Lithuania).
He has started his scientific carrier at Kaunas Polytechnic Institute faculty of Computer Science since 1980, later continuing his researcher's and teacher's work in Electro-technical and Mechanical faculties, focusing on the Nanotechnologies and Mechatronics. Since 2000 until now he continues his researcher's and teacher's work in Faculties of Economics and Management and Social Sciences at Kaunas University of Technology, focusing on the innovations, regional development and economy. Since 2003 he has started his carrier at the Lithuanian Regional Research Institute and at present he is the President of this Institute, located in Lithuania, Kaunas, K. Donelaicio str. 60 . He has published over 30 papers in peer reviewed journals and conference proceedings, as well 8 books for the students.

Asooc.Prof., Dr. Rimantas Dapkus research interests are regional politics, sustainable economy grow, strategy planning, public administration, rural and cities planning, marketing, finances, innovations, project management, human resources, e-democracy, as well as industry development and automation, nanotechnologies and mechatronics. $\mathrm{He}$ also provides consultation for National and Regional authorities in the field of sustainable development and strategy planning, national and international programs development and projects implementation, consultation of private companies on business development issues. For his outstanding activitie has been granted with Diplomas of the Lithuanian Supreme Council and American Institute of Bibliography.

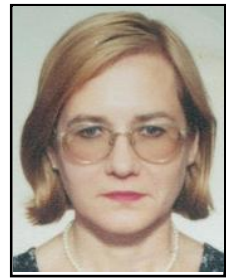

Dalia Streimikiene was born in Lithuania in 1962. In 1985 she has graduated Kaunas Polytechnic Institute (at present Kaunas University of Technology) and become diploma engineer-economist. In 1997 she obtained a degree of doctor of the social sciences and in 2005 she has passed the procedures of habilitation in social sciences at Vilnius Gediminas Technical University (Vilnius, Lithuania).

She has started her scientific carrier in 1985 at the Lithuanian Energy Institute and continues her work there as a senior researcher until now. Since 1997 she is a professor of Vilnius University Kaunas Faculty of Humanities and she has been involved in research dealing with sustainable economic development since 1998. The main sphere of her interest is environmental policies and their impact on sustainable economic development. She is included in the expert's roster of United Nations Climate Change Convention (UNFCCC) on GHG emission inventories, assessment of climate change policies and measures in energy sector. She has been regularly invited to work as an expert on sustainable development, climate change mitigation and environmental issues for European Commission, United Nations Economic Commission for Europe, United Nations Development Program, UNFCCC Secretariat, World Energy Council, Nordic Council of Ministers etc. She provides also consultancy services for Ministry of Environment and takes part in preparation on National communications to UNFCCC.

Prof. Dr. Dalia Streimikiene has big experience in international and local project management. During the last years she has won tenders and successfully lead studies on climate change mitigation policies development in Lithuanian energy sector. Also she led the international project financed by Nordic Council of Ministers "The Challenges of Kyoto protocol for Baltic States Energy Sectors" conducted together with researchers from Latvia and Estonia (2005-2006). Dalia Streimikiene was involved in the several important coordinated research projects financed by International Atomic Energy agency (IAEA): "Sustainable energy development indicators, (2002-2005); "GHG emission reduction strategies and energy supply options (2006-2009); "Comparative assessment of geological nuclear waste and CO2 storage (2009-2012). Also she has been involved in the following EC FM 6 and 7 Projects: Cost Assessment for Sustainable Energy Systems, CASES (2006-2008); Probabilistic Long Term Assessment of Energy Scenarios, PLANETS (2008-2010). D. Streimikiene has published about 100 papers in peer reviewed journals. 